\title{
Uncoupling Between Dinitrogen Fixation and Primary Productivity in the Eastern Mediterranean Sea
}

Eyal Rahav

Barak Herut

Noga Stambler

Edo Bar-Zeev

Margaret R. Mulholland

Old Dominion University, mmulholl@odu.edu

Follow this and additional works at: https://digitalcommons.odu.edu/oeas_fac_pubs

Part of the Biogeochemistry Commons, Ecology and Evolutionary Biology Commons, Microbiology Commons, and the Oceanography Commons

\section{Repository Citation}

Rahav, Eyal; Herut, Barak; Stambler, Noga; Bar-Zeev, Edo; and Mulholland, Margaret R., "Uncoupling Between Dinitrogen Fixation and Primary Productivity in the Eastern Mediterranean Sea" (2013). OEAS Faculty Publications. 170.

https://digitalcommons.odu.edu/oeas_fac_pubs/170

\section{Original Publication Citation}

Rahav, E., Herut, B., Stambler, N., Bar-Zeev, E., Mulholland, M.R., \& Berman-Frank, I. (2013). Uncoupling between dinitrogen fixation and primary productivity in the eastern Mediterranean Sea. Journal of Geophysical Research: Biogeosciences, 118(1), $195-202$. doi: http://dx.doi.org/10.1002/jgrg.20023 


\title{
Uncoupling between dinitrogen fixation and primary productivity in the eastern Mediterranean Sea
}

\author{
Eyal Rahav, ${ }^{1}$ Barak Herut, ${ }^{2}$ Noga Stambler, ${ }^{1}$ Edo Bar-Zeev, ${ }^{1}$ \\ Margaret R. Mulholland, ${ }^{3}$ and Ilana Berman-Frank ${ }^{1}$ \\ Received 13 April 2012; revised 16 December 2012; accepted 22 December 2012; published 25 February 2013.
}

[1] In the nitrogen $(\mathrm{N})$-impoverished photic zones of many oceanic regions, prokaryotic organisms fixing atmospheric dinitrogen $\left(\mathrm{N}_{2}\right.$; diazotrophs) supply an essential source of new nitrogen and fuel primary production. We measured dinitrogen fixation and primary productivity (PP) during the thermally stratified summer period in different water regimes of the oligotrophic eastern Mediterranean Sea, including the Cyprus Eddy and the Rhodes Gyre. Low $\mathrm{N}_{2}$ fixation rates were measured $\left(0.8-3.2 \mu \mathrm{mol} \mathrm{N} \mathrm{m}^{-2} \mathrm{~d}^{-1}\right)$ excluding 10 -fold higher rates in the Rhodes Gyre and Cyprus Eddy $\left(\sim 20 \mu \mathrm{mol} \mathrm{N} \mathrm{m}{ }^{-2} \mathrm{~d}^{-1}\right)$. The corresponding PP increased from east to west $\left(200-2500 \mu \mathrm{mol} \mathrm{C} \mathrm{m} \mathrm{m}^{-2} \mathrm{~d}^{-1}\right)$, with relatively higher productivity recorded in the Rhodes Gyre and Cyprus Eddy (2150 and $2300 \mu \mathrm{mol} \mathrm{C} \mathrm{m}{ }^{-2} \mathrm{~d}^{-1}$, respectively). These measurements demonstrate that $\mathrm{N}_{2}$ fixation in the photic zone of the eastern Mediterranean Sea contributes only negligibly by direct inputs to PP (i.e., cyanobacterial diazotrophs) and is in fact uncoupled from PP. By contrast, $\mathrm{N}_{2}$ fixation is significantly coupled to bacterial productivity and to net heterotrophic areas, suggesting that heterotrophic $\mathrm{N}_{2}$ fixation may in fact be significant in this ultraoligotrophic system. This is further substantiated by the high $\mathrm{N}_{2}$ fixation rates we measured from aphotic depths and by the results of phylogenetic analysis in other studies showing an abundance of heterotrophic diazotrophs.

Citation: Rahav, E., B. Herut, N. Stambler, E. Bar-Zeev, M. R. Mulholland, and I. Berman-Frank (2013), Uncoupling between dinitrogen fixation and primary productivity in the eastern Mediterranean Sea, J. Geophys. Res. Biogeosci., 118, 195-202 doi:10.1002/jgrg.20023.

\section{Introduction}

[2] The Mediterranean Sea is the largest semienclosed marine basin in the world, and it is characterized by low dissolved inorganic concentrations of nitrogen $(\mathrm{N})$ and phosphorus (P) [Krom et al., 1991; Bethoux et al., 1992; reviewed in Krom et al., 2010] that are rapidly taken up and recycled by phytoplankton and bacteria [Psarra et al., 2005; Thingstad et al., 2005; Tanaka et al., 2007, 2011]. The increasing gradient of subsurface inorganic $\mathrm{N}$ and $\mathrm{P}$ concentrations from east to west greatly influences the photosynthetic biomass [Moutin and Raimbault, 2002; Krom, 2004]. Chlorophyll concentrations and primary productivity (PP) reflect this geographical gradient and increase from east to west [D'Ortenzio and Ribera D'Alcala, 2009], with the lowest chlorophyll and primary production found in the Levantine basin of the eastern Mediterranean

\footnotetext{
${ }^{1}$ Mina and Everard Goodman Faculty of Life Sciences, Bar-Ilan University, Ramat Gan, Israel.

${ }^{2}$ Israel Oceanographic and Limnological Research, National Institute of Oceanography, Haifa, Israel.

${ }^{3}$ Department of Ocean, Earth, and Atmospheric Sciences, Old Dominion University, Norfolk, Virginia, USA.

Corresponding author: I. Berman-Frank, Mina and Everard Goodman Faculty of Life Sciences, Bar-Ilan University, Ramat Gan 52900, Israel (ilana.berman-frank@biu.ac.il)

(C)2013. American Geophysical Union. All Rights Reserved. 2169-8953/13-0/10.1002/jgrg.20023
}

Sea especially during the thermally stratified summer period [Yacobi et al., 1995; Gotsis-Skretas et al., 1999; Bosc et al., 2004; Ignatiades et al., 2009; reviewed in Siokou-Frangou et al., 2010, and Berman-Frank and Rahav, 2012].

[3] Dissolved inorganic phosphorus has traditionally been considered the limiting nutrient for phytoplankton, especially in the eastern Mediterranean basin [Krom et al., 1991; Zohary and Robarts, 1998; Van Wambeke et al., 2002; Tanaka et al., 2009]. However, limitation of primary and bacterial production by dissolved inorganic nitrogen availability as well as co-limitation of dissolved inorganic nitrogen and phosphorus also occur [Thingstad et al., 2005; Tanaka et al., 2011]. The limited availability of dissolved inorganic nitrogen sources in the upper photic zone and diazotrophic access to an almost infinite supply of atmospheric dinitrogen $\left(\mathrm{N}_{2}\right)$ could thus provide diazotrophs with a competitive edge in this environment.

[4] Although not limited by nitrogen $(\mathrm{N})$ as many marine autotrophs are, diazotrophs require dissolved inorganic phosphorus, dissolved Fe, and other micronutrients to supply their cellular demand for the metabolically expensive process of $\mathrm{N}_{2}$ fixation [Postgate, 1979]. In many oceanic areas, diazotrophy is limited by dissolved inorganic phosphorus [Sanudo-Wilhelmy et al., 2001; Wu et al., 2003; Moutin et al., 2008; Moore et al., 2009], dissolved Fe [Rueter, 1988; Kustka et al., 2003; Capone et al., 1998], or both [Mills et al., 2004; see review in Sohm et al., 2011; Zehr and Kudela, 2011]. 
[5] $\mathrm{N}_{2}$ fixation further controls total primary production [Falkowski, 1997] as the supply of new nitrogen to the $\mathrm{N}$-poor surface waters of the ocean by diazotrophs usually stimulates both autotrophic and heterotrophic communities of the planktonic and microbial food webs [Carpenter and Capone, 2008]. Thus, $\mathrm{N}_{2}$ fixation should be positively correlated to primary production in two ways: (1) directly via photoautotrophic diazotrophs currently assumed to be the dominant component of the diazotrophic community in the photic zone, with sunlight providing the required energy for the energetically expensive process of $\mathrm{N}_{2}$ fixation, and (2) indirectly via the contribution and recycling of the products of this "new N" (i.e., assimilated N, ammonia leakage, breakdown of diazotrophic blooms, etc.) stimulating primary production by non-diazotrophic photoautotrophs.

[6] In the ultraoligotrophic eastern Mediterranean Sea, very low rates of $\mathrm{N}_{2}$ fixation have been measured in the photic layer over the past 6 years [Ibello et al., 2010; Bonnet et al., 2011; Yogev et al., 2011]. The regulating factors leading to these low $\mathrm{N}_{2}$ fixation rates have not yet been elucidated as dissolved $\mathrm{Fe}$ sources are assumed sufficient in the eastern Mediterranean Sea [Statham and Hart, 2005; Theodosi et al., 2010], while nutrient enrichment studies including $\mathrm{P}, \mathrm{Fe}$, and Saharan dust yielded variable responses of $\mathrm{N}_{2}$ fixation in different stations [Ridame et al., 2011]. Diazotroph characterization via molecular phylogenetic identification indicates that many of the nifH sequences are homologous with heterotrophic bacterioplankton rather than with phototrophic cyanobacteria [Man-Aharonovich et al., 2007; Yogev et al., 2011].

[7] In this study, we evaluated the contribution and relationship of $\mathrm{N}_{2}$ fixation from the photic layer to primary production in different water regimes of the eastern Mediterranean Sea. To this end, we measured in situ $\mathrm{N}_{2}$ and carbon fixation from different depths within the photic zone and performed on-board microcosm experiments in 11 different locations throughout the Levantine basin over three consecutive years (2007-2009) during the stratified period.

\section{Materials and Methods}

\subsection{Sampling Locations}

[8] Water samples were collected on board the $\mathrm{R} / \mathrm{V}$ Mediterranean Explorer for stations located within the Cyprus Eddy and Rhodes Gyre as well as pelagic stations uninfluenced by eddy circulation (Stations 2, 6, and 10) during the ISRLEV transect (July 2009) and on board R/V Shikmona for Stations H06, IL04, IL13, and IL16 during the SESAME Levantine basin transect (September 2008) [see Yogev et al., 2011, for details]. Stations T1 and T2 off the Israeli coastline were also routinely sampled for 3 years [see Yogev et al., 2011, for details]. Note that stations uninfluenced by the Cyprus Eddy and Rhodes Gyre are hereafter referred to as "background" stations. All sampling locations are illustrated in Figure 1, and the exact locations are specified in Table 1.

[9] Seawater was sampled using Niskin bottles $(8 \mathrm{~L})$ mounted on a rosette equipped with a CTD (Seabird 19 Plus), a fluorometer (Turner designs, Cyclops-7) for realtime chlorophyll $a$ evaluation, and a PAR sensor (Seabird 19 Plus).

\subsection{Inorganic Nutrients}

[10] Duplicate water samples were collected in $15 \mathrm{~mL}$ acid-washed plastic scintillation vials. Nutrients were determined using a segmented flow Technicon AutoAnalyzer II system as described by Krom et al. [1991] and Kress and Herut [2001]. The precision values of nitrate + nitrite, phosphate, and silicic acid measurements were $0.02,0.003$, and $0.06 \mu \mathrm{M}$, respectively. The limit of detection (two times the standard deviation of the blank) was $0.075 \mu \mathrm{M}$ for nitrate + nitrite, $0.008 \mu \mathrm{M}$ for phosphate, and $0.03 \mu \mathrm{M}$ for silicic acid.

[11] For phosphorus enrichment experiments, orthophosphate $\left(\mathrm{PO}_{4}^{-3}\right)$ solution (Sigma) was added into acid-clean $4.5 \mathrm{~L}$ polycarbonate Nalgene bottles, bringing the water to a final concentration of $100 \mathrm{nM} \mathrm{P}$.

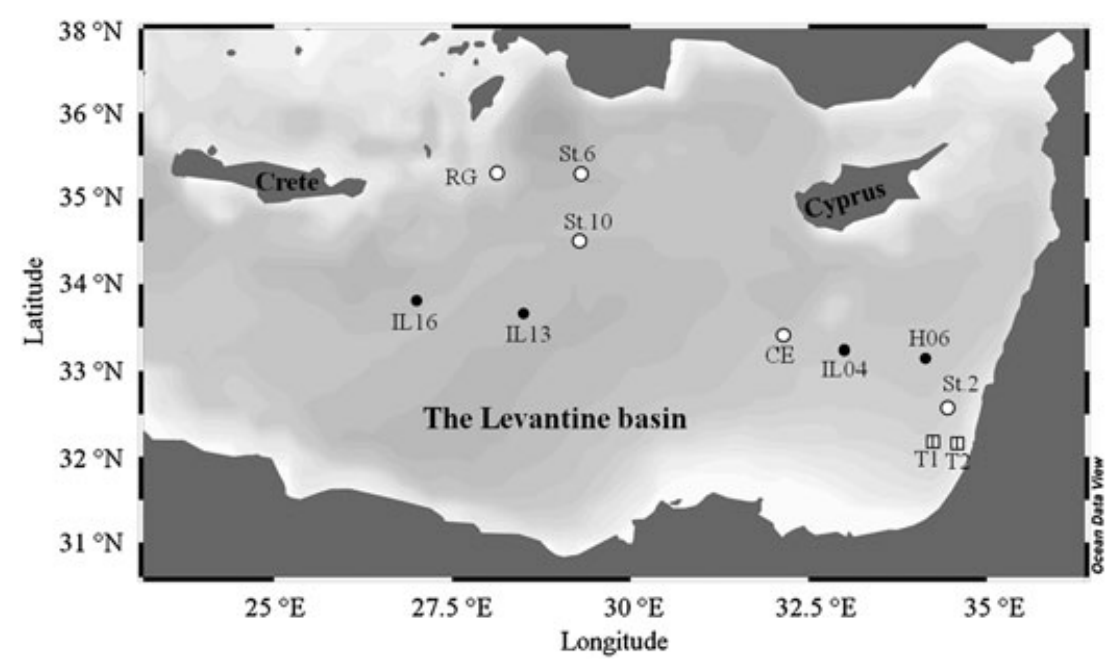

Figure 1. Map showing station locations of the ISRALEV cruise during July 2009 (white circles), stations sampled during the SESAME cruise (September 2008) (black circles), and stations sampled monthly off the Israeli coastal shelf (T1 and T2) during the stratified period (square symbols). 
RAHAV ET AL:: $\mathrm{N}_{2}$ FIXATION AND PRIMARY PRODUCTIVITY IN THE EASTERN MEDITERRANEAN SEA

Table 1. Summary of the Sampling Locations and Dates at the Upper $150 \mathrm{~m}^{\mathrm{a}}$

\begin{tabular}{|c|c|c|c|c|c|c|c|c|}
\hline Station & Latitude $(\mathrm{N})$ & Longitude (E) & Cruise & Sampling Date & Temperature $\left({ }^{\circ} \mathrm{C}\right)$ & Salinity & $\mathrm{NO}_{2}+\mathrm{NO}_{3}\left(\mathrm{mMm}^{-2}\right)$ & $\mathrm{PO}_{4}\left(\mathrm{mM} \mathrm{m}^{-2}\right)$ \\
\hline 2 & 32.5 & 34.4 & ISRLEV & July 2009 & $17.2-28.3$ & $39.3-39.5$ & 28 & 2.9 \\
\hline Cyprus Eddy & 33.4 & 32.1 & ISRLEV & July 2009 & $17.2-26.7$ & $39.3-39.4$ & 26 & 2.8 \\
\hline 6 & 35.3 & 29.3 & ISRLEV & July 2009 & $15.7-25.7$ & $39.1-39.5$ & 33 & 2.3 \\
\hline 10 & 34.5 & 29.3 & ISRLEV & July 2009 & $15.5-26.3$ & $39.1-39.5$ & 53 & 2.6 \\
\hline Rhodes Gyre & 35.3 & 28.1 & ISRLEV & July 2009 & $14.9-23.6$ & $39.0-39.4$ & 136 & 2.8 \\
\hline $\mathrm{H} 06$ & 33.1 & 34.1 & SESAME & September 2008 & $16.7-28.7$ & $39.2-39.8$ & 34 & 1.5 \\
\hline IL04 & 33.2 & 33.0 & SESAME & September 2008 & $16.9-28.4$ & $39.3-39.7$ & 15 & 1.6 \\
\hline IL13 & 33.6 & 28.5 & SESAME & September 2008 & $16.2-26.9$ & $39.1-39.4$ & 36 & 2.3 \\
\hline IL16 & 33.8 & 27.0 & SESAME & September 2008 & $15.6-26.0$ & $39.0-39.4$ & 28 & 5.8 \\
\hline $\mathrm{T} 1$ & 32.2 & 34.5 & Routine & Averaged summer & $18.1-27.7$ & $39.3-39.7$ & 21 & 1.9 \\
\hline $\mathrm{T} 2$ & 32.2 & 34.2 & Routine & Averaged summer & $18.1-27.6$ & $39.3-39.6$ & 23 & 1.9 \\
\hline
\end{tabular}

${ }^{\mathrm{a}}$ Temperature and salinity are presented as ranges and inorganic nutrients $\left(\mathrm{NO}_{2}+\mathrm{NO}_{3}\right.$ and $\left.\mathrm{PO}_{4}\right)$ are shown as integrated concentrations.

\subsection{Dinitrogen Fixation}

[12] Rates of $\mathrm{N}_{2}$ fixation were measured on field samples using the ${ }^{15} \mathrm{~N}_{2}$ assimilation technique described by Montoya et al. [1996] and Mulholland et al. [2006]. Water was added into $4.5 \mathrm{~L}$ polycarbonate Nalgene bottles, sealed with septum tops, and spiked with $9 \mathrm{~mL}$ of ${ }^{15} \mathrm{~N}_{2}$ (99\%). For each sampling depth, triplicate bottles were spiked with ${ }^{15} \mathrm{~N}_{2}$ and triplicate bottles were incubated with the natural abundance of $\mathrm{N}_{2}$. All bottles were incubated on deck under ambient surface seawater temperatures and covered with neutral density screening adjusted to simulate light levels at the sampling depth. According to experience in the eastern Mediterranean Sea [Bar-Zeev et al., 2008; Yogev et al., 2011], incubations were 24-30 h in duration. Incubations were terminated by filtration onto precombusted $25 \mathrm{~mm} \mathrm{GF/F}$ filters. Filters were dried overnight $(\sim 10 \mathrm{~h})$ at $60^{\circ} \mathrm{C}$ and analyzed on a Europa 20/20 mass spectrometer equipped with an automated nitrogen and carbon analyzer preparation module. For isotope ratio mass spectrometry, standard curves to determine $\mathrm{N}$ and $\mathrm{C}$ mass were done with each sample run. Samples were run only when standard curves had $R^{2}$ values $>0.99$. At masses $>4.7 \mu \mathrm{g} \mathrm{N}$, the precision for the atom percent ${ }^{15} \mathrm{~N}$ measurement was $\pm 0.0001 \%$ based on daily calibrations made in association with sample runs and calibrations averaged over runs made over several years. For most of the results reported here, the masses were $>4.7 \mu \mathrm{g} \mathrm{N}$. However, samples with $<4.7 \mu \mathrm{g} \mathrm{N}$ were only used if the precision was $0.0001 \%$ for that sample run. Standard masses ranged from 1.2 to $100 \mu \mathrm{g} \mathrm{N}$ and from 9.4 to $800 \mu \mathrm{g}$ C. In addition to daily standard curves, reference standards and standards run as samples were run every six to eight samples. $\mathrm{N}_{2}$ fixation rates were calculated using a mixing model [Montoya et al., 1996] with the N solubility factors from Weiss [1970]. Based on natural abundance, $\mathrm{N}$ mass on the filters, incubation times, and precision of the mass spectrometer, our calculated detection limit for ${ }^{15} \mathrm{~N}$ uptake was $0.02 \mathrm{nmol} \mathrm{L}^{-1} \mathrm{~d}^{-1}$ [Yogev et al., 2011]. Integrated areal $\mathrm{N}_{2}$ fixation rates were calculated from surface down to $150 \mathrm{~m}$ at all stations (4-6 $\mathrm{m}$ depths for each station in total).

\subsection{Primary Productivity}

[13] Photosynthetic carbon fixation rates were estimated using ${ }^{13} \mathrm{C}$ [Mulholland and Bernhardt, 2005]. Water samples were placed in triplicate clear $4.5 \mathrm{~L}$ polycarbonate Nalgene bottles, amended with (99\%) $\mathrm{NaH}^{13} \mathrm{CO}_{3}$ (Sigma) to obtain $1 \%$ of the ambient dissolved inorganic carbon, and incubated under the same conditions and bottles as those applied in the ${ }^{15} \mathrm{~N}$ incubations described above $(n=3$ for each depth). Triplicate parallel dark bottles were also incubated and subtracted from the light bottles to correct for dark carbon fixation. PP was integrated over $24 \mathrm{~h}$. Incubations were terminated and analyzed as described above for the ${ }^{15} \mathrm{~N}_{2}$ uptake. The contribution of $\mathrm{N}_{2}$ fixation to the $\mathrm{N}$ demand for PP was estimated using the measured particulate $\mathrm{C} / \mathrm{N}$ ratio obtained for each sample.

\subsection{Bacterial Productivity}

[14] Bacterial productivity was estimated using the ${ }^{3} \mathrm{H}$-leucine (Amersham; specific activity: $160 \mathrm{Ci} \mathrm{mmoL}^{-1}$ ) incorporation method [Simon et al., 1990; Simon et al., 1992]. Triplicate $(1.7 \mathrm{~mL})$ samples were incubated with 200 nmol $\mathrm{L}^{-1}{ }^{3} \mathrm{H}$-leucine for $4-8 \mathrm{~h}$ at in situ temperatures in the dark. Preliminary experiments indicated that this was a saturating level of ${ }^{3} \mathrm{H}$-leucine and that incorporation was linear during this time period (data not shown). Triplicate trichloroacetic acid (TCA)-killed samples served as controls. The incubations were terminated with the addition of $100 \mu \mathrm{L}$ of cold TCA $(100 \%)$ to the vials, and samples were stored at $4^{\circ} \mathrm{C}$ until processing, which was carried out several days after the cruise. After the addition of scintillation cocktail (ULTIMA-GOLD), the samples were counted using a TRI-CARB 2100 TR (PACKARD) scintillation counter. Bacterial productivity $(\mathrm{BP})$ and $\mathrm{BP} / \mathrm{PP}$ ratio measurements were carried out for the same depths as those for $\mathrm{N}_{2}$ fixation and PP (4-6 $\mathrm{m}$ depths at the upper $150 \mathrm{~m}$ ).

\section{Results}

[15] The water column was characterized by typical summer oligotrophic conditions, with a well-stratified mixed surface layer $(\sim 20 \mathrm{~m})$. Water temperatures ranged from $29^{\circ} \mathrm{C}$ at the surface layer to $\sim 17^{\circ} \mathrm{C}$ at the bottom of the photic layer $(\sim 150 \mathrm{~m})$. Salinity ranged between 39.8 and 38.7 for the surface and $150 \mathrm{~m}$ depth, respectively. The cyclonic Rhodes Gyre was also stratified, with cool $\left(\sim 23^{\circ} \mathrm{C}\right)$ and less saline $(\sim 39)$ waters ascending up to $40 \mathrm{~m}$, while temperature and salinity reached the background levels (i.e., $>26^{\circ} \mathrm{C}$ and 39.4 , respectively) at the surface layer $(5 \mathrm{~m})$. The anticyclonic Cyprus Eddy was characterized by a warm and saline top layer $\left(\sim 27^{\circ} \mathrm{C}\right.$ and 39.4 , respectively). Below the thermocline $(\sim 30 \mathrm{~m})$, temperature decreased to $\sim 17^{\circ} \mathrm{C}$, while salinity remained unchanged at $\sim 39.3$ (Table 1).

[16] The depth-integrated (top $150 \mathrm{~m}$ ) $\mathrm{NO}_{2}+\mathrm{NO}_{3}$ and $\mathrm{PO}_{4}$ concentrations throughout the Levantine basin ranged from 15 to $53 \mathrm{mM} \mathrm{m}^{-2}$ and from 1.5 to $5.8 \mathrm{mM} \mathrm{m}^{-2}$ for $\mathrm{N}$ and 
$\mathrm{P}$, respectively, with the higher concentrations found at the more western stations of the Levantine basin. Within the Rhodes Gyre, high areal $\mathrm{NO}_{2}+\mathrm{NO}_{3}$ concentrations were observed $\left(136 \mathrm{mM} \mathrm{m}^{-2}\right)$, while sixfold lower values were measured $\left(26 \mathrm{mM} \mathrm{m}^{-2}\right)$ within the Cyprus Eddy. No significant differences between the gyre and the eddy were observed for the $\mathrm{PO}_{4}$ integrated values $\left(\sim 3 \mathrm{mM} \mathrm{m}^{-2}\right)$ (Table 1).

[17] Measured PP rates across the Levantine basin revealed an east-west gradient $\left(R^{2}=0.71, n=11, P<0.001\right)$ (Figure 2a). The PP values at the easternmost stations were lower by a factor of 10 compared to those at the western Levantine basin stations $\left(\sim 200\right.$ and $>2000 \mu \mathrm{mol} \mathrm{C} \mathrm{m} \mathrm{m}^{-2}$ $\mathrm{d}^{-1}$, respectively) (Figure $2 \mathrm{a}$ ). Areal PP rates within the Cyprus Eddy and Rhodes Gyre were 2150 and $2300 \mu \mathrm{mol}$ $\mathrm{C} \mathrm{m} \mathrm{m}^{-2} \mathrm{~d}^{-1}$, respectively (Figure $2 \mathrm{a}$ ), regardless of the physical characteristics of the gyre or eddy.

[18] Areal $\mathrm{N}_{2}$ fixation rates were low throughout all sampled stations in the Levantine basin. In contrast to the PP rates (Figure 2a), no clear east-west gradient was observed for the $\mathrm{N}_{2}$ fixation rates (Figure 2b). $\mathrm{N}_{2}$ fixation rates ranged from $0.8 \mu \mathrm{mol} \mathrm{N} \mathrm{m} \mathrm{N}^{-2} \mathrm{~d}^{-1}$ at the station closest to the coast to $3.2 \mu \mathrm{mol} \mathrm{N} \mathrm{m} \mathrm{N}^{-2}$ at Station IL16. The highest areal $\mathrm{N}_{2}$ fixation rates were within the Rhodes Gyre and Cyprus Eddy (19.5 and $22.5 \mu \mathrm{mol} \mathrm{N} \mathrm{m}^{-2} \mathrm{~d}^{-1}$, respectively), higher by 1 order of magnitude than those in all other eastern Mediterranean Sea stations uninfluenced by gyre or eddy circulations (Figure 2b).

[19] The percent contribution of the biologically fixed $\mathrm{N}$ to $\mathrm{PP}$ at the background stations (ranging from $0.7 \%$ to $2 \%$, $n=96$ ) was threefold to sixfold lower than that in both gyres $(>6 \%, n=24)$ (Figure 2c). In the eastern Levantine stations, we calculated a higher contribution of the fixed $\mathrm{N}$ to PP $(2 \%)$ than in the more western stations $(0.7 \%)$, yet these did not differ significantly ( $t$ test, $P>0.05$ ) (Figure $2 \mathrm{c}$ ).

[20] Our results show that during the stratified period, excluding the Rhodes Gyre and Cyprus Eddy, $\mathrm{N}_{2}$ fixation was uncoupled from PP across the Levantine basin. Other studies from varying oceanic regions demonstrated positive correlation of PP with $\mathrm{N}_{2}$ fixation in the photic illuminated layer under stratified conditions (Figure $3, R^{2}=0.54, P=2 \times 10^{-6}$, $n=26$ ). Our results contrast with these studies. We did not find a significant correlation in the Levantine basin $(P=0.3, n=19)$ (Figure 3). Moreover, differential responses between $\mathrm{N}_{2}$ fixation, $\mathrm{PP}$, and bacterial production resulted when surface seawater $(5 \mathrm{~m})$ was artificially enriched with $100 \mathrm{nM} \mathrm{PO}_{4}^{-3}$ (Figure 4) to examine the $\mathrm{P}$ limitation of dia-

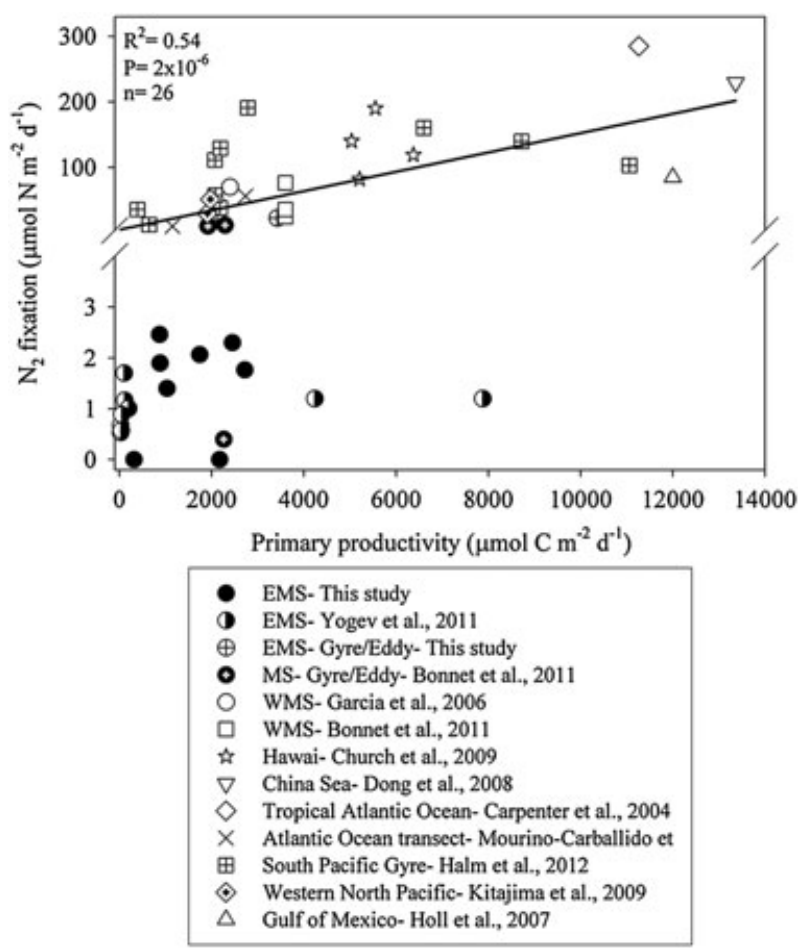

Figure 3. Correlation between $\mathrm{N}_{2}$ fixation rates and PP for the illuminated photic depths (depending on the study area, this depth ranged from 100 to $150 \mathrm{~m}$ ). Data were compiled from this study, the eastern Mediterranean Sea (EMS) [Yogev et al., 2011], anti-cyclonic eddies within the Mediterranean Sea [Bonnet et al., 2011], the DYMAMED station in the WMS [Garcia et al., 2006], Station ALOHA near Hawaii [Church et al., 2009], the South China Sea [Dong et al., 2008], the tropical and subtropical western North Pacific [Kitajima et al., 2009], the Gulf of Mexico [Holl et al., 2007], the Atlantic Ocean [Mourino-Carballido et al., 2011], the Baltic Sea [Ohlendieck et al., 2007], and the South Pacific Gyre [Halm et al., 2012].
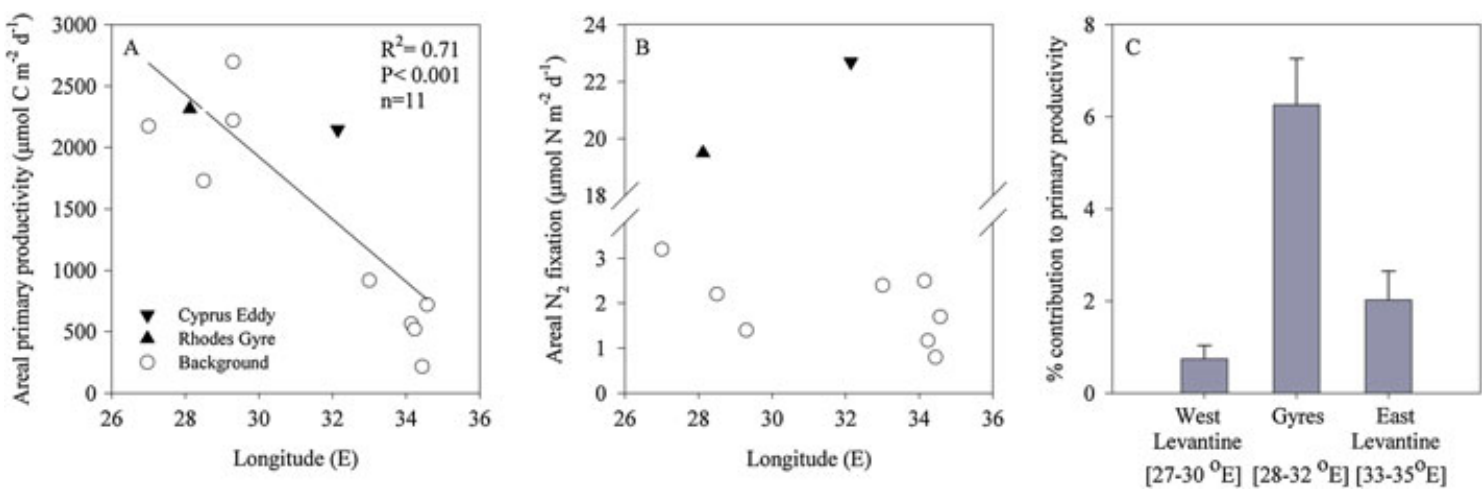

Figure 2. Areal (0-150 m) PP (a), $\mathrm{N}_{2}$ fixation (b), and percent contribution of $\mathrm{N}_{2}$ fixation to PP in the Levantine basin (c) during the stratified summer months from the different water provinces of the Levantine basin. White symbols represent the uninfluenced Levantine basin stations, while black triangles represent the Cyprus Eddy and Rhodes Gyre. 
RAHAV ET AL: $\mathrm{N}_{2}$ FIXATION AND PRIMARY PRODUCTIVITY IN THE EASTERN MEDITERRANEAN SEA
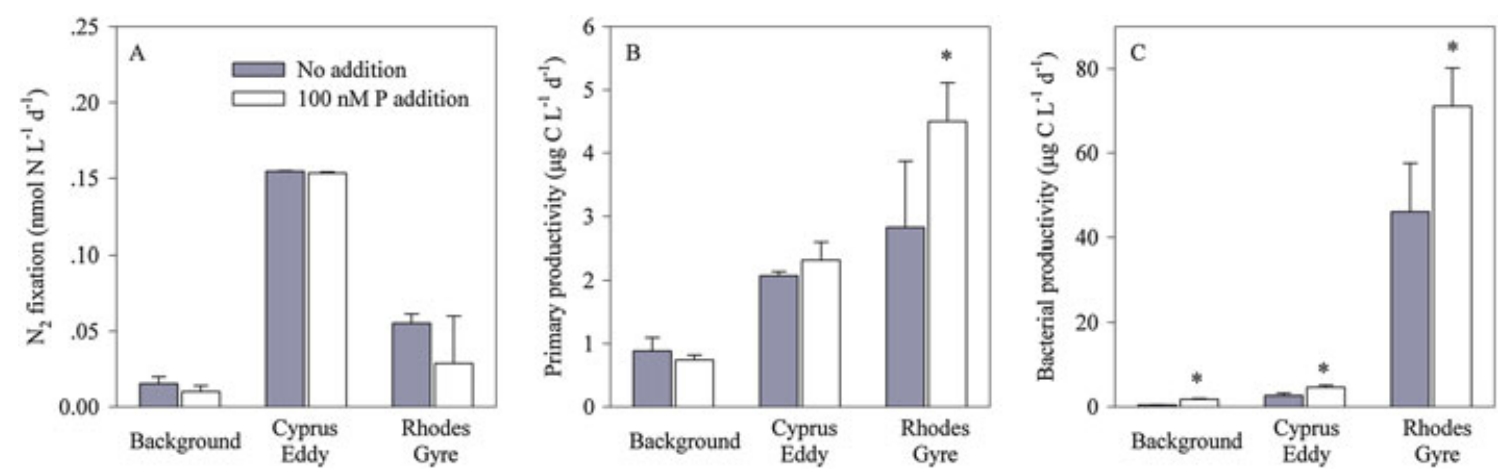

Figure 4. The influence of $\mathrm{P}$ enrichment on $\mathrm{N}_{2}$ fixation rates (a), PP (b), and BP (c) from surface waters $(5-20 \mathrm{~m})$ of representative stations of Levantine pelagic water (Station 10), the Cyprus Eddy, and the Rhodes Gyre during July 2009. The gray bars represent the control treatments (no addition), while the white bars represent the rates measured after incubation for 24-30 h with $100 \mathrm{nM} \mathrm{PO}$ addition. Values are averages and error bars are standard deviations of three independent replicates performed for each control and treatment incubation. The asterisks above the columns represent statistically significant differences (one-way ANOVA and a Fisher LSD means comparison test, $P<0.05$ ) for mean values of $\mathrm{P}$ additions between stations.

zotrophy. $\mathrm{PO}_{4}^{-3}$ additions did not stimulate $\mathrm{N}_{2}$ fixation at any of the selected stations (Figure 4a). PP was enhanced significantly only at the Rhodes Gyre (Figure 4b), while bacterial production increased significantly at all experimental stations (Figure 4c). A 4-fold increase was observed in BP rates in the uninfluenced station (i.e., background), while an $\sim 1.5$ fold increase was measured within the gyre and eddy (Figure 4c).

\section{Discussion}

[21] Our data substantiate previous studies reporting typically low rates of $\mathrm{N}_{2}$ fixation for the Mediterranean Sea, specifically the eastern Mediterranean Sea [Ibello et al., 2010; Yogev et al., 2011; Bonnet et al., 2011; Ridame et al., 2011; Berman-Frank and Rahav, 2012]. Moreover, the results of this study distinctly demonstrate that summertime $\mathrm{N}_{2}$ fixation within the photic zone of the Mediterranean Levantine basin provides a minor contribution to total production (Figure $2 \mathrm{c}$ ) and is uncoupled from primary production, excluding isolated "hot spots" such as the Rhodes Gyre or Cyprus Eddy (Figure 3).

[22] Why are $\mathrm{N}_{2}$ fixation and PP uncoupled in the eastern Mediterranean Sea? This question warrants special attention especially as our results contrast with the significant and positive correlation found between these processes from several oceanic ecosystems as well as the more productive western Mediterranean Sea (WMS) $\left(R^{2}=0.54, P=2 \times 10^{-6}\right.$, $n=26$ ) (Figure 3). High concurrent rates of $\mathrm{N}_{2}$ fixation and PP were associated with the dominance of species of the diazotrophic cyanobacterium Trichodesmium in the South China Sea [Dong et al., 2008] and the Atlantic Ocean [Fernandez et al., 2010; Mourino-Carballido et al., 2011]. The contribution of Trichodesmium to PP was $11.6 \%$ in the outer Sanya Bay of the China Sea [Dong et al., 2008] and as high as $22 \%-44 \%$ in the equatorial Atlantic Gyre and South Atlantic Gyre [Fernandez et al., 2010; MourinoCarballido et al., 2011]. Furthermore, Trichodesmium accounted on average for about $47 \%$ of total depth-integrated primary production in the North Atlantic Ocean [Carpenter et al.,
2004]. The positive correlation between $\mathrm{PP}$ and $\mathrm{N}_{2}$ fixation demonstrated in Figure 3 is not limited to Trichodesmium and filamentous cyanobacteria comprising the diazotrophic community. At Station ALOHA (Hawaii Ocean Time-series program in the central North Pacific Subtropical Gyre), the diazotrophic community was composed mainly of unicellular organisms in the late winter and early spring [Church et al., 2009], while in the South Pacific Gyre, gamma proteobacteria and unicellular photoheterotrophic Group A prevailed [Halm et al., 2012]. Other studies demonstrated that diazotrophy from both Trichodesmium and diatom-cyanobacterial diazotrophic associations positively correlated with increased C drawdown [Subramaniam et al., 2008]. In the WMS and the central Ligurian Sea (NW Mediterranean Sea), coupling between $\mathrm{N}_{2}$ fixation and PP was positive, excluding several measurements from DYFAMED during the oligotrophic stratified summer, when high $\mathrm{N}_{2}$ fixation rates were associated with low PP rates [Garcia et al., 2006; Bonnet et al., 2011]. Similarly, within the Cyprus Eddy and Rhodes Gyre (this study), $\mathrm{N}_{2}$ fixation and PP measurements corresponded with the linear regression produced for the more productive environments described above (Figure 3).

[23] Presently, published data including both $\mathrm{N}_{2}$ fixation and PP are limited, so we could not verify whether the uncoupling shown between $\mathrm{N}_{2}$ fixation and PP from the eastern Mediterranean Sea data corresponds to other areas of low, photic zone, $\mathrm{N}_{2}$ fixation $\left(<10-20 \mu \mathrm{mol} \mathrm{N} \mathrm{m}^{-2} \mathrm{~d}^{-1}\right)$ (Figure 3). We believe that this uncoupling will be found in other ultraoligotrophic environments and should be further investigated.

[24] These examples illustrate the general coupling found between $\mathrm{N}_{2}$ fixation rates (and diazotrophic organisms) and PP in the photic layer and contrast with our findings for the eastern Mediterranean Sea demonstrating uncoupling between these two processes $(n=19, P=0.3)$ (Figure 3). This uncoupling in the eastern Mediterranean Sea may be explained by examining the characteristic composition and structure of the pelagic primary producers and the resulting microbial food web. In the ultraoligotrophic eastern Mediterranean basin, primary production is attributed predominantly to the 
picophytoplankton-mainly picoeukaryotes, nanoeukaryotes, prochlorophytes, and Synechococcus types [Yacobi et al., 1995; Psarra et al., 2000; Tanaka et al., 2007; Ignatiades et al., 2009; Denis et al., 2010]. Microphytoplankton blooms occur only occasionally [Ignatiades et al., 2009], with higher biomass blooms limited mostly to coastlines or gyres [SiokouFrangou et al., 2010] and diazotroph blooms being a rare event [Spatharis et al., 2012]. Recent genomic characterization of eastern Mediterranean Sea surface waters yielded predominant sequences corresponding to Alphaproteobacteria (SAR11-like and Rhodobacterales), Cyanobacteria (Synechococcus and high light-adapted Prochlorococcus), and diverse uncultured Gammaproteobacteria [Feingersch et al., 2009]. Furthermore, the extremely limited concentrations of dissolved inorganic nitrogen and phosphorus cause interspecific competition between phytoplankton and heterotrophic bacteria for nutrients and induce efficient biological recycling of dissolved inorganic and organic nutrient pools [Pitta et al., 2005; Lagaria et al., 2010]. Thus, genomic analysis of the eastern Mediterranean Sea demonstrated an enrichment of sequences related to phosphate and/or phosphonate uptake and assimilation [Feingersch et al., 2009]. Rapid uptake and utilization of $\mathrm{P}$ sources by heterotrophic bacteria can lead to systems with elevated BP and a decline in PP as measured in a large-scale P fertilization experiment in the eastern Mediterranean Sea (CYCLOPS) [Pitta et al., 2005; Thingstad et al., 2005].

[25] The BP/PP ratio is not diazotroph specific yet provides a measure of the metabolic status of the environment, i.e., whether the environment is predominantly heterotrophic or autotrophic (similar to the bacterial carbon demand to PP ratio described by Lagaria et al. [2010]). A ratio $<1$ indicates higher autotrophic fixation of carbon relative to heterotrophic carbon fixation; conversely, when this ratio is $>1$, there is higher heterotrophic production. In this study, the $\mathrm{BP} / \mathrm{PP}$ ratio was $<1$ for the pelagic background stations uninfluenced by vortexes (0.2-0.5), demonstrating autotrophic metabolism; $\sim 1$ at the Cyprus Eddy; and $>1$ at the Rhodes Gyre $(\sim 12)$, indicating heterotrophic metabolism.

[26] The metabolic status suggestive of heterotrophic metabolism in the Rhodes Gyre and Cyprus Eddy corresponds with the highest areal $\mathrm{N}_{2}$ fixation rates we measured during the summer stratification $\left(19-23 \mu \mathrm{mol} \mathrm{N} \mathrm{m}{ }^{-2} \mathrm{~d}^{-1}\right)$, while the lowest $\mathrm{N}_{2}$ fixation was obtained from the Levantine background stations $\left(\sim 2 \mu \mathrm{mol} \mathrm{N} \mathrm{m} \mathrm{d}^{-1}\right)$ (Figure $2 \mathrm{~b}$ ), corresponding with previous reports for the eastern Mediterranean Sea [Ibello et al., 2010; Bonnet et al., 2011; Yogev et al., 2011]. Moreover, the maximum volumetric rates of $\mathrm{N}_{2}$ fixation $\left(>0.3 \mathrm{nmol} \mathrm{N} \mathrm{L} \mathrm{N}^{-1}\right.$ ) were measured within the Rhodes Gyre at aphotic depths $>130 \mathrm{~m}$, suggesting a greater contribution by heterotrophic diazotrophs from the aphotic layer.

[27] Although we presently do not have a molecular fingerprint of the diazotroph communities at our stations, we did not observe any conspicuous populations of cyanobacterial or diatom-cyanobacterial diazotrophic associations throughout our samplings in the upper photic layers of the eastern Mediterranean Sea over the past 7 years. While phototrophic (cyanobacterial) diazotrophs enjoy a direct (solar) energy source for the energetically expensive process of $\mathrm{N}_{2}$ fixation, the presence and contribution of non-cyanobacterial heterotrophic diazotrophs in marine system are being increasingly recognized [Zehr and Turner,
2001; Riemann et al., 2010; Fernandez et al., 2011]. Some of these organisms have also been found in the eastern Mediterranean Sea close to our current stations [Man-Aharonovich et al., 2007; Ibello et al., 2010; Yogev et al., 2011]. During the BOUM campaign (June 2008), the diazotrophic populations at Station $C$ (located within the Cyprus Eddy) were predominantly $<3 \mu \mathrm{m}$ and composed of such bacteria as Bradyrhizobium, Rhizobium, and Gammaproteobacteria [Bonnet et al., 2011; Le Moal et al., 2011; Ridame et al., 2011]. The $\mathrm{N}_{2}$ fixation rates of these populations in the Cyprus Eddy (subsurface Station $\mathrm{C}$ waters from $8 \mathrm{~m}$ : $0.09 \mathrm{nmol} \mathrm{N} \mathrm{L}{ }^{-1} \mathrm{~d}^{-1}$ [Bonnet et al., 2011; Ridame et al., 2011]) are similar to our rates measured 1 year later: $\sim 0.15 \mathrm{nmol} \mathrm{N} \mathrm{L}^{-1} \mathrm{~d}^{-1}$ from surface to $150 \mathrm{~m}$.

[28] To investigate the parameters controlling the variability in $\mathrm{N}_{2}$ fixation, we examined the chemical and physical characteristics that would enable 1 order of magnitude higher $\mathrm{N}_{2}$ fixation rates in the gyre and eddy compared to the surrounding Levantine waters. Phosphorus, essential for the energetically expensive process of $\mathrm{N}_{2}$ fixation [Postgate, 1979], has previously been considered limiting for diazotrophy in the eastern Mediterranean Sea [Rees et al., 2006; Krom et al., 2010]. Our midsummer transect of the eastern Mediterranean Sea occurred when surface waters were depleted in dissolved inorganic phosphate concentrations that were below or close to their analytical detection limits and were also similar for the upper $150 \mathrm{~m}$ between the Rhodes Gyre and the Cyprus Eddy. $\mathrm{PO}_{4}$ additions to surface seawater samples did not stimulate diazotrophy at any of the stations (Figure 4a). We conclude that during the ISRLEV cruise (July 2009; see Table 1), dissolved inorganic phosphorus was not the limiting factor for $\mathrm{N}_{2}$ fixation, in contrast to a June 2008 transect (BOUM) where similar concentrations of $\mathrm{PO}_{4}$ additions to the Cyprus Eddy waters increased $\mathrm{N}_{2}$ fixation rates by threefold over the unamended controls [Ridame et al., 2011]. Co-limitation of diazotrophs by other microelements could occur as exhibited by addition of Saharan dust (containing elements such as Fe, Mo, and $\mathrm{Zn}$ ) to seawater that enhanced $\mathrm{N}_{2}$ fixation in surface waters fivefold in the Cyprus Eddy relative to the surrounding water mass [Ridame et al., 2011]. However, we did not examine this issue here and suggest further experimentation is required to understand what controls both autotrophic diazotrophy and heterotrophic diazotrophy in the eastern Mediterranean Sea.

[29] During our transects (summer stratified period), the fixed nitrogen $\left(\mathrm{NO}_{2}+\mathrm{NO}_{3}\right)$ concentrations in the Rhodes Gyre were sixfold higher than those measured in the Cyprus Eddy (Table 1), while PP rates at the gyre and eddy were similar (Figure 2a). These indicate that the increase in fixed $\mathrm{N}$ sources in the Rhodes Gyre was not sufficient to sustain higher PP with the available concentrations of dissolved inorganic phosphorus and thus allude to $\mathrm{PP}$, which is $\mathrm{P}$ limited as typically described for the eastern Mediterranean Sea [Krom et al., 1991; Zohary and Robarts, 1998; VanWambeke et al., 2002; Tanaka et al., 2009]. Indeed, we confirmed that during our sampling, $\mathrm{P}$ availability limited phytoplankton in the Rhodes Gyre, as PP increased when surface water bioassays were enriched with $\mathrm{PO}_{4}$ (Figure 4b). In the Cyprus Eddy, $\mathrm{PP}$ did not increase in $\mathrm{PO}_{4}$-amended treatments (Figure 4b) and may thus be $\mathrm{N}$ and $\mathrm{P}$ co-limited as described in the BOUM [Ridame et al., 2011; Tanaka et al., 2011] and CYCLOPS [Zohary et al., 2005; Tanaka 
et al., 2007] campaigns. The substantial increase in bacterial production when $\mathrm{PO}_{4}$ was added (1.5-fold to 4-fold), compared to unamended controls (Figure 4c), highlights the competitive ability of heterotrophic bacteria to efficiently take up and utilize inorganic $\mathrm{P}$ as previously observed in the eastern Mediterranean Sea [Thingstad et al., 2005]. Furthermore, non-diazotrophic heterotrophic bacteria may in fact outcompete diazotrophs if another resource (e.g., dissolved $\mathrm{Fe}$ ) is limiting. These interactions place an additional control on photosynthetic autotrophs and diazotrophic biomass.

[30] In conclusion, our data demonstrate that $\mathrm{N}_{2}$ fixation in the photic zone of the eastern Mediterranean Sea contributes only negligibly by direct inputs to PP (i.e., cyanobacterial diazotrophs) and is in fact uncoupled from PP. In contrast, $\mathrm{N}_{2}$ fixation is significantly coupled to $\mathrm{BP}$ and high $\mathrm{N}_{2}$ fixation coincides with net heterotrophic areas. We suggest that in this system, where heterotrophic bacteria compete with the primary producers for the limited nutrients [Pitta et al., 2005; Thingstad et al., 2005; Lagaria et al., 2010], heterotrophic $\mathrm{N}_{2}$ fixation can be significant and may also extend deep into the aphotic depths.

[31] Acknowledgments. This research was supported by Israel Science Foundation grants (996/08) to I.B.-F. and B.H. and by the Southern European Seas: Assessing and Modelling Ecosystem changes project (SESAME) (036949, EUF6) awarded to B.H. This study is in partial fulfillment of a PhD thesis by Eyal Rahav from Bar-Ilan University. We are very grateful for the hard work and help provided by the crew of the R/V Mediterranean Explorer and R/V Shikmona. We thank Gal Dishon, Maxim Rubin, Mor Samuelson, Barak Ben-David, Adi Levi, and Eran Brokovitch for technical help during the cruise. We thank Steve Groom and the PML Remote Sensing Group for satellite information.

\section{References}

Bar-Zeev, E., T. Yogev, D. Man-Aharonovich, N. Kress, B. Herut, O. Beja, and I. Berman-Frank (2008), Seasonal dynamics of the endosymbiotic, nitrogen-fixing cyanobacterium Richelia intracellularis in the Eastern Mediterranean Sea, ISME J., 2(9), 911-923.

Berman-Frank, I., and E. Rahav (2012), Nitrogen fixation as a source for new production in the Mediterranean Sea: A review. In Life in the Mediterranean Sea: A Look at Habitat Changes, edited by N. E. Stambler, pp 199-226, Nova Science Publishers, NY.

Bethoux, J. P., P. Morin, C. Madec, and B. Gentili (1992), Phosphorus and nitrogen behavior in the Mediterranean-sea, Deep Sea Res., Part A, 39(9A), 1641-1654.

Bonnet, S., O. Grosso, and T. Moutin (2011), Planktonic dinitrogen fixation in the Mediterranean Sea: a major biogeochemical process during the stratified period?, Biogeosciences, 8, 1197-1225.

Bosc, E., A. Bricaud, and D. Antoine (2004), Seasonal and interannual variability in algal biomass and primary production in the Mediterranean Sea, as derived from 4 years of SeaWiFS observations, Global Biogeochem. Cycles, 18(1), GB1005, doi:1010.1029/2003 GB002034.

Capone, D. G., A. Subramaniam, J. P. Montoya, M. Voss, C. Humborg, A. M. Johansen, R. L. Siefert, and E. J. Carpenter (1998), An extensive bloom of the $\mathrm{N}_{2}$ fixing cyanobacterium Trichodesmium erythraeum in the central Arabian Sea, Mar. Ecol. Prog. Ser., 172, 281-292.

Carpenter, E. J., and D. Capone (2008), Nitrogen Fixation in the Marine Environment in Nitrogen Fixation in the Marine Environment edited by D. Capone, A. D. Bronk, R. M. Mulholland and E. J. Carpenter, pp. 141-198, Elsevier, Academic Press, San Diego.

Carpenter, E. J., A. Subramaniam, and D. G. Capone (2004), Biomass and primary productivity of the cyanobacterium Trichodesmium spp. in the tropical N Atlantic ocean, Deep Sea Res., Part I, 51(2), 173-203.

Church, M. J., C. Mahaffey, R. M. Letelier, R. Lukas, J. P. Zehr, and D. M. Karl (2009), Physical forcing of nitrogen fixation and diazotroph community structure in the North Pacific subtropical gyre, Global Biogeochem. Cycles, 23, GB2020, doi:2010.1029/2008 GB003418.

Denis, M., M. Thyssen, V. Martin, B. Manca, and F. Vidussi (2010), Ultraphytoplankton basin-scale distribution in the Eastern Mediterranean Sea in winter: link to hydrodynamism and nutrients, Biogeosciences, 7, 2227-2244.
Dong, J. D., Y. Y. Zhang, Y. S. Wang, S. Zhang, and H. K. Wang (2008), Spatial and seasonal variations of Cyanobacteria and their nitrogen fixation rates in Sanya Bay, South China Sea, Scientia Marina, 72, 239-251.

D'Ortenzio, F., and M. Ribera D'Alcala (2009), On the trophic regimes of the Mediterranean Sea: a satellite analysis, Biogeosciences, 6(2), 139-148.

Falkowski, P. G. (1997), Evolution of the nitrogen cycle and its influence on the biological sequestration of $\mathrm{CO}_{2}$ in the ocean, Nature, 387(6630), $272-275$.

Feingersch, R., M. T. Suzuki, M. Shmoish, I. Sharon, G. Sabehi, F. Partensky, and O. Beja (2009), Microbial community genomics in Eastern Mediterranean Sea surface waters, ISME, 4(1), 78-87.

Fernandez, A., B. Mourino-Carballido, A. Bode, M. Varela, and E. Maranon (2010), Latitudinal distribution of Trichodesmium spp. and $\mathrm{N}_{2}$ fixation in the Atlantic Ocean, Biogeosciences, 7, 3167-3176.

Fernandez, C., L. Farias, and O. Ulloa (2011), Nitrogen Fixation in Denitrified Marine Waters, PLoS One, 6, doi:10.1371/journal.pone.0020539.

Garcia, N., P. Raimbault, E. Gouze, and V. Sandroni (2006), Nitrogen fixation and primary production in western Mediterranean, Comptes Rendus Biologies, 329, 742-750.

Gotsis-Skretas, O., K. Pagou, M. Moraitou-Apostolopoulou, and L. Ignatiades (1999), Seasonal horizontal and vertical variability in primary production and standing stocks of phytoplankton and zooplankton in the Cretan Sea and the Straits of the Cretan Arc (March 1994-Jannuary 1995), Progress in Oceanography, 44(4), 625-649.

Halm, H., P. Lam, T. G. Ferdelman, G. Lavik, T. Dittmar, J. LaRoche, S. D'Hondt, and M. M. M. Kuypers (2012), Heterotrophic organisms dominate nitrogen fixation in the South Pacific Gyre, ISME J., 6(6), 1238-1249.

Holl, C. M., A. M. Waite, S. Pesant, P. A. Thompson, and J. P. Montoya (2007), Unicellular diazotrophy as a source of nitrogen to Leeuwin Current coastal eddies, Deep Sea Res., Part II, 54(8-10), 1045-1054.

Ibello, V., C. Cantoni, S. Cozzi, and G. Civitarese (2010), First basin-wide experimental results on $\mathrm{N}_{2}$ fixation in the open Mediterranean Sea, Geophys. Res. Lett., 37, doi:10.1029/2009g1041635.

Ignatiades, L., O. Gotsis-Skretas, K. Pagou, and E. Krasakopoulou (2009), Diversification of phytoplankton community structure and related parameters along a large-scale longitudinal east-west transect of the Mediterranean Sea, J. Plankton Res., 31, 411-428.

Kitajima, S., K. Furuya, F. Hashihama, S. Takeda, and J. Kanda (2009), Latitudinal distribution of diazotrophs and their nitrogen fixation in the tropical and subtropical western North Pacific, Limnol. Oceanogr., 54 (2), 537-547.

Kress, N., and B. Herut (2001), Spatial and seasonal evolution of dissolved oxygen and nutrients in the Southern Levantine Basin (Eastern Mediterranean Sea): chemical characterization of the water masses and inferences on the N: P ratios, Deep Sea Res., Part I, 48, 2347-2372.

Krom, M. D., B. Herut, and R. F. C. Mantoura (2004), Nutrient budget for the Eastern Mediterranean: Implications for phosphorus limitation, Limnol. Oceanogr., 49(5), 1582-1592.

Krom, M. D., K. C. Emeis, and P. Van Cappellen (2010), Why is the Eastern Mediterranean phosphorus limited?, Progress in Oceanography, $85,236-244$.

Krom, M. D., N. Kress, S. Brenner, and L. I. Gordon (1991), Phosphorus limitation of primary productivity in the Eastern Mediterranean Sea, Limnol. Oceanogr., 36, 424-432.

Kustka, A. B., S. A. Sanudo-Wilhelmy, E. J. Carpenter, D. Capone, J. Burns, and W. G. Sunda (2003), Iron requirements for dinitrogen- and ammonium-supported growth in cultures of Trichodesmium (IMS 101): Comparison with nitrogen fixation rates and iron: carbon ratios of field populations, Limnol. Oceanogr., 48(5), 1869-1884.

Lagaria, A., S. Psarra, F. Lefevre, F. Van Wambeke, C. Courties, M. Pujo-Pay, L. Oriol, T. Tanaka, and U. Christaki (2010), The effects of nutrient additions on particulate and dissolved primary production in surface waters of three Mediterranean eddies, Biogeosciences, 7, 8919-8952.

Le Moal, M., H. Collin, and I. C. Biegala (2011), Intriguing diversity among diazotrophic picoplankton along a Mediterranean transect: a dominance of Rhizobia, Biogeosciences, 8(3), 827-840.

Man-Aharonovich, D., N. Kress, E. Bar Zeev, I. Berman-Frank, and O. Beja (2007), Molecular ecology of nifH genes and transcripts in the Eastern Mediterranean Sea, Environ. Microbiol., 9(9), 2354-2363.

Mills, M. M., C. Ridame, M. Davey, J. La Roche, and R. J. Geider (2004), Iron and phosphorus co-limit nitrogen fixation in the Eastern tropical North Atlantic, Nature, 429, 292-294.

Montoya, J. P., M. Voss, P. Kahler, and D. G. Capone (1996), A simple, high-precision, high-sensitivity tracer assay for $\mathrm{N}_{2}$ fixation, Appl. Environ. Microbiol., 62, 986-993.

Moore, C. M., et al. (2009), Large-scale distribution of Atlantic nitrogen fixation controlled by iron availability, Nature Geosciences, 2(12), 867-871. Mourino-Carballido, B., R. Grana, A. Fernandez, A. Bode, M. Varela, J. F. Dominguez, J. Escanez, D. de Armas, and E. Maranon (2011), 


\section{RAHAV ET AL:: $\mathrm{N}_{2}$ FIXATION AND PRIMARY PRODUCTIVITY IN THE EASTERN MEDITERRANEAN SEA}

Importance of $\mathrm{N}_{2}$ fixation versus nitrate eddy diffusion along a latitudinal transect in the Atlantic Ocean, Limnol. Oceanogr., 56, 999-1007.

Moutin, T., and P. Raimbault (2002), Primary production, carbon export and nutrients availability in western and Eastern Mediterranean Sea in early summer 1996 (MINOS cruise), J. Marine Syst., 33, 273-288.

Moutin, T., D. M. Karl, S. Duhamel, P. Rimmelin, P. Raimbault, B. A. S. Van Mooy, and H. Claustre (2008), Phosphate availability and the ultimate control of new nitrogen input by nitrogen fixation in the tropical Pacific Ocean, Biogeosciences, 5(1), 95-109.

Mulholland, M. R., and P. W. Bernhardt (2005), The effect of growth rate, phosphorus concentration, and temperature on $\mathrm{N}_{2}$ fixation, carbon fixation, and nitrogen release in continuous cultures of Trichodesmium IMS101, Limnol. Oceanogr., 50(3), 839-849.

Mulholland, M. R., P. W. Bernhardt, C. A. Heil, D. A. Bronk, and J. M. O'Neil (2006), Nitrogen fixation and release of fixed nitrogen by Trichodesmium spp. in the Gulf of Mexico, Limnol. Oceanogr., 51(4), $1762-1776$.

Ohlendieck, U., K. Gundersen, M. Meyerhofer, P. Fritsche, K. Nachtigall, and B. Bergmann (2007), The significance of nitrogen fixation to new production during early summer in the Baltic Sea, Biogeosciences, 4, 63-73.

Pitta, P., N. Stambler, T. Tanaka, T. Zohary, A. Tselepides, and F. Rassoulzadegan (2005), Biological response to P addition in the Eastern Mediterranean Sea. The microbial race against time, Deep Sea Res., Part II, 52(22-23), 2961-2974.

Postgate, J. (1979), Nitrogen-fixation and the future of the world's foodsupply, Biologist, 26(4), 165-166.

Psarra, S., A. Tselepides, and L. Ignatiades (2000), Primary productivity in the oligotrophic Cretan Sea (NE Mediterranean): seasonal and interannual variability, Prog. Oceanogr., 46(2-4), 187-204.

Psarra, S., T. Zohary, M. D. Krom, R. F. C. Mantoura, T. Polychronaki, N. Stambler, T. Tanaka, A. Tselepides, and T. F. Thingstad (2005), Phytoplankton response to a Lagrangian phosphate addition in the Levantine Sea (Eastern Mediterranean), Deep Sea Res., Part II, 52(22-23), 2944-2960.

Rees, A. P., C. S. Law, and E. M. S. Woodward (2006), High rates of nitrogen fixation during an in-situ phosphate release experiment in the Eastern Mediterranean Sea, Geophys. Res. Lett., 33(10), doi:10.1029/ $2006 \mathrm{~g} 1025791$.

Ridame, C., M. Le Moal, C. Guieu, E. Ternon, I. C. Biegala, S. L’Helguen, and M. Pujo-Pay (2011), Nutrient control of $\mathrm{N}_{2}$ fixation in the oligotrophic Mediterranean Sea and the impact of Saharan dust events, Biogeosci. doi:10.5194/bgd-5198-2629-2011.

Riemann, L., H. Farnelid, and G. F. Steward (2010), Nitrogenase genes in non-cyanobacterial plankton: prevalence, diversity and regulation in marine waters, Aquat. Microb. Ecol., 61(3), 225-237.

Rueter, J. G. (1988), Iron stimulation of photosynthesis and nitrogen-fixation in Anabaena-7120 and Trichodesmium (Cyanophyceae), J. Phycol., 24(2), 249-254.

Sanudo-Wilhelmy, S. A., A. B. Kustka, C. J. Gobler, D. A. Hutchins, M. Yang, K. Lwiza, J. Burns, D. G. Capone, J. A. Raven, and E. J. Carpenter (2001), Phosphorus limitation of nitrogen fixation by Trichodesmium in the central Atlantic Ocean, Nature, 411(6833), 66-69.

Simon, M., A. L. Alldredge, and F. Azam (1990), Bacterial carbon dynamics on marine snow, Mar. Ecol. Prog. Ser., 65, 205-211.

Simon, M., B. C. Cho, and F. Azam (1992), Significance of bacterial biomass in lakes and the ocean - comparison to phytoplankton biomass and biogeochemical implications, Mar. Ecol. Prog. Ser., 86, 103-110.
Siokou-Frangou, I., U. Christaki, M. G. Mazzocchi, M. Montresor, M. Ribera. D'Alcala, D. Vaque, and A. Zingone (2010), Plankton in the open Mediterranean Sea: a review, Biogeosci., 7, 1543-1586.

Sohm, J. A., E. A. Webb, and D. G. Capone (2011), Emerging patterns of marine nitrogen fixation, Nat Rev. Microbiol. 9(7), 499-508.

Spatharis, S., N. Skliris, A. Meziti, and K. Kormas (2012), First record of a Trichodesmium erythraeum bloom in the Mediterranean Sea: a result of climate change?, Can. Fish., 69(8), 1444-1455.

Statham, P. J., and V. Hart (2005), Dissolved iron in the Cretan Sea (Eastern Mediterranean), Limnol. Oceanogr., 50(4), 1142-1148.

Subramaniam, A., et al. (2008), Amazon River enhances diazotrophy and carbon sequestration in the tropical North Atlantic Ocean, Proc. Natl. Acad. Sci. U. S. A., 105(30), 10,460-10,465

Tanaka, T., et al. (2007), Microbial community structure and function in the Levantine Basin of the Eastern Mediterranean, Deep Sea Res., Part I, 54, 1721-1743.

Tanaka, T., T. F. Thingstad, J. M. Gasol, C. Cardelus, J. Jezbera, M. M. Sala, K. Simek, and F. Unrein (2009), Determining the availability of phosphate and glucose for bacteria in P-limited mesocosms of NW Mediterranean surface waters, Aquat. Microb. Ecol., 56(1), 81-91.

Tanaka, T., et al. (2011), Lack of P-limitation of phytoplankton and heterotrophic prokaryotes in surface waters of three anticyclonic eddies in the stratified Mediterranean Sea, Biogeosciences, 8, 525-538.

Theodosi, C., Z. Markaki, and N. Mihalopoulos (2010), Iron speciation, solubility and temporal variability in wet and dry deposition in the Eastern Mediterranean, Marine Chemistry, 120(1-4), 100-107.

Thingstad, T. F., et al. (2005), Nature of phosphorus limitation in the ultraoligotrophic Eastern Mediterranean, Science, 309(5737), 1068-1071.

Van Wambeke, F., U. Christaki, A. Giannokourou, T. Moutin, and K. Souvemerzoglou (2002), Longitudinal and vertical trends of bacterial limitation by phosphorus and carbon in the Mediterranean Sea, Microb. Ecol., 43(1), 119-133.

Weiss, R. F. (1970), Solubility of nitrogen, oxygen and argon in water and seawater, Deep Sea Res. Oceanogr. Abstr., 17, 721-735.

Wu, J. F., S. W. Chung, L. S. Wen, K. K. Liu, Y. L. L. Chen, H. Y. Chen, and D. M. Karl (2003), Dissolved inorganic phosphorus, dissolved iron, and Trichodesmium in the oligotrophic South China Sea, Global Biogeochem. Cycles, 17(1).

Yacobi, Y. Z., T. Zohary, N. Kress, A. Hecht, R. D. Robarts, M. Waiser, and A. M. Wood (1995), Chlorophyll distribution throughout the southeastern Mediterranean in relation to the physical structure of the water mass, Journal of Marine Systems, 6(3), 179-190.

Yogev, T., E. Rahav, E. Bar-Zeev, D. Man-Aharonovich, N. Stambler, N. Kress, O. Beja, M. R. Mulholland, B. Herut, and I. Berman-Frank (2011), Is dinitrogen fixation significant in the Levantine Basin, East Mediterranean Sea?, Environ. Microbiol., 13, 854-871.

Zehr, J. P., and P. J. Turner (2001), Nitrogen fixation: Nitrogenase genes and gene expression, Methods in Microbiology, 30, 271-286.

Zehr, J. P., and R. M. Kudela (2011), Nitrogen Cycle of the Open Ocean: From Genes to Ecosystems, in Annual Review of Marine Science, $3,197-225$.

Zohary, T., and R. D. Robarts (1998), Experimental study of microbial $\mathrm{P}$ limitation in the Eastern Mediterranean, Limnol. Oceanogr., 43(3), 387-395.

Zohary, T., et al. (2005), P-limited bacteria but N and P co-limited phytoplankton in the Eastern Mediterranean - a microcosm experiment, Deep Sea Res., Part II, 52, 3011-3023. 